\title{
REVIEW
}

\section{USE OF MEASUREMENT TOOLS FOR SCREENING OF POSTOPERATIVE DELIRIUM IN NURSING PRACTICE}

\author{
Mária Balková, Martina Tomagová \\ Department of Nursing, Jessenius Faculty of Medicine in Martin, Commenius University in Bratislava, Slovakia
}

Received October 11, 2017; Accepted March 21, 2018. Copyright: This is an open access article distributed under the terms of the Creative Commons Attribution International License (CC BY). http://creativecommons.org/licenses/by/4.0/

\begin{abstract}
Aim: The aim of the literary overview was to search quantitative research studies focusing on screening for postoperative patient delirium by nurses with the aid of measurement tools; and, afterwards, to compare the tools used with respect to their psychometric characteristics and use in clinical nursing practice. Design: Overview study - literary review. Methods: Electronic databases were searched for relevant documents (i.e., Web of Science, SCOPUS, Science Direct, and Summon Discovery Tool), from the period 1990-2017. Key words used for databases were: postoperative delirium, screening, tool, validity, reliability, psychometric characteristic, and nursing, combined with Boolean operators. Results: A total of 253 documents were identified. Based on the chosen selection criteria, eight studies dealing with screening of postoperative delirium were included in the analysis and overview. The following measurement tools were used in the studies: the Confusion Assessment Method for Intensive Care Units - CAM-ICU, the Nursing Delirium Screening Scale - Nu-DESC, the NEECHAM Confusion Scale, the Delirium Observation Screening Scale - DOSS, and the Intensive Care Delirium Screening Checklist - ICDSC. The tool with the optimum psychometric characteristics for detection of postoperative delirium is the CAM-ICU tool. Conclusion: The results of the studies analysed indicate the importance of the implementation of a relevant tool for screening of postoperative delirium. It is essential to examine the psychometric characteristics and usability of screening tools in Slovak clinical practice.
\end{abstract}

Keywords: nursing, postoperative delirium, psychometric characteristic, reliability, screening, tool, validity.

\section{Introduction}

Postoperative delirium is a common complication of surgical treatment. It can have a negative impact on the condition of patients and on their postoperative treatment and rehabilitation, and may prolong hospitalization, and increase mortality (Grover, Kate, 2012; Mitášová et al., 2012; Winter, Steurer, Dullenkopf, 2015; Poikajärvi et al., 2017). A protracted and untreated delirious condition worsens patient prognosis, and is a risk factor for violent and suicidal behaviour, irreversible decrease of functional abilities, and institutionalization of patients. It can result in dementia or other organic brain syndromes and, in extreme cases, even death (Zmeková, 2003).

From a pathological view, delirium is related to a generalized disruption of oxidative mechanisms, and disruption of energetic metabolism and the innerbody environment (ionic imbalance, osmolarity,

Corresponding author: Mária Balková, Department of Nursing, Jessenius Faculty of Medicine in Martin, Commenius University in Bratislava, Malá Hora 5, Martin, Slovakia; email: mbalkova@jfmed.uniba.sk acid-base balance, and disruption of synthesis of substances necessary for structural and functional brain integrity). With regard to neurotransmitter imbalances, it is associated with cholinergic deficit and increase in dopaminergic activity (Doubek, Jirák, 2013).

Typical clinical symptoms of delirium are acute confusion with simultaneous occurrence of disturbance of consciousness, attention, perception, thinking, memory, psychomotor behaviour, emotivity, and the sleep-wake cycle. Decreased tenacity and attention shifting, hypoprosexia, and increased suggestibility are manifested. Thinking is either accelerated or slowed, fragmented, incoherent and disorganized; patients have transient bizarre delusions, erroneous identifications, illusions, and hallucinations. The main somatic symptoms of delirium include neurological symptoms - tremor, ataxia, dysarthria, dysgraphia, agnosia, aphasia, or, in some cases, epileptic seizures. There are frequent symptoms of vegetative dysfunctions such as increase in body temperature, sweating, tachycardia, fluctuating blood pressure, tachypnoea, nausea, vomiting, diarrhoea and others (Praško, Suchý, 
Kubínek, 2011; Doubek, Jirák, 2013). Based on clinical symptoms we can specify three subtypes of delirium: hyperactive, hypoactive, and combined (Jirák, 2005; Uhrová, Klempiŕr, 2011). Delirium isan etiologically nonspecific global cerebral dysfunction, alleviated by treatment involving induction of systemic or toxic noxas (Zmeková, 2003).

Brooks et al. (2014) state that according to several studies, postoperative delirium results in a combination of predisposing and precipitating factors. Predisposing factors involve older age of patients, alcohol abuse, dependence on addictive substances, comorbidity and impaired cognition (present in preoperative condition), depression, unsatisfactory preoperative nutritional and functional condition, hypoxia, and abnormal levels of glycaemia. Precipitating factors involve medication, physical limitations, sedation, analgesia, postoperative pain, prolonged rest on bed, and sleep deprivation. Precipitating risk factors can often be influenced, and represent an area in which interventions aimed at prevention and management of postoperative delirium could be most effective (Brooks et al., 2014).

For continuous monitoring of patients, it is necessary to identify those with high risk of delirium, and perform preventive interventions to reduce delirium in advance (van den Boogaard, Pickkers, Schoonhoven, 2010). Since the causes of delirium are multifactorial and risk factors variable, it is difficult to predict which patients will develop postoperative delirium (Brooks, 2014). According to Harroche, St-Louis, Gagnon (2014), screening of delirium in practice is conducted subjectively, without using validated tools, despite the fact that screening and early treatment of delirium can prevent many complications, and significantly reduce patient morbidity (Harroche, St-Louis, Gagnon, 2014). For assessment of postoperative delirium, there are several validated tools for delirium screening and diagnosis, or for the gaging of its severity (Wofford, Vacchiano, 2011; Grover, Kate, 2012). Since delirium occurs in a wide range of medical institutions, it is not always possible for it to be assessed by a psychiatric specialist. Therefore, many validated screening tools are designed for use by medical staff without psychiatric training (Grover, Kate, 2012). Data selected by measurement tools support systematic communication regarding patient condition to different care providers, contribute to the planning of care and management of treatment, determine whether the involvement of particular members of an interdisciplinary team is required, are an impulse for further targeted assessment, and can be used for comparison of care results achieved (Bóriková, 2015).

Despite its current importance and severity, postoperative delirium is still an underestimated entity, and its early and systematic detection is absent in current Slovak nursing practice.

\begin{abstract}
Aim
The aim of the literary overview was to search for quantitative research studies focusing on screening for postoperative delirium performed by nurses with the help of measurement tools; and, afterwards, to compare the tools used regarding their psychometric characteristics and use in clinical nursing practice.
\end{abstract}

\section{Methods}

\section{Design}

A literary review.

\section{Eligibility criteria}

To achieve the aims, the analysis consisted of quantitative studies (based on the selection criteria) focusing on the screening of postoperative delirium by measurement tools, with defined psychometric qualities. Recommendations for nursing practice were included. Further conditions required that the full text of the study be published in a scientific peer-reviewed journal, and that publications used in the study be from the defined period: 1990-2017, due to the introduction of the Confusion Assessment Method tool - CAM (Inouye et al., 1990) as a new method for delirium detection in this period. The analysis excluded qualitative studies, studies of a literary review type, overview articles, abstracts, studies not defined clearly, theoretical articles, and ethical debates.

\section{Sources}

Electronic databases available to Comenius University were used (i.e.: Web of Science, SCOPUS, Science Direct, and the Summon Discovery Tool).

\section{Search}

To search for relevant documents, mentioned electronic databases were used in the period 1990-2017. Key words used for databases were: postoperative delirium, screening, tool, validity, reliability, psychometric characteristic, and nursing, combined with Boolean operators OR and AND.

\section{Study selection}

A total of 253 records were identified. After the selection process, eight studies were included in the analysis and overview. The following were excluded: 
studies with unclearly defined measurement tools for postoperative delirium screening, or an undefined sample of respondents; studies of patients with types of delirium other than postoperative - e.g., delirium tremens, delirium in patients with dementia, and delirium in patients in palliative care; studies with samples of patients under 18; or studies lacking recommendations for the use of tools for nursing practice. Also excluded were studies in which the psychometric qualities of the tools were absent. The process of study selection can be found in Figure 1.

\section{Data analysis}

Quantitative research studies focusing on screening for postoperative delirium performed by nurses were analysed with accent to their psychometric characteristics and use in clinical nursing practice.

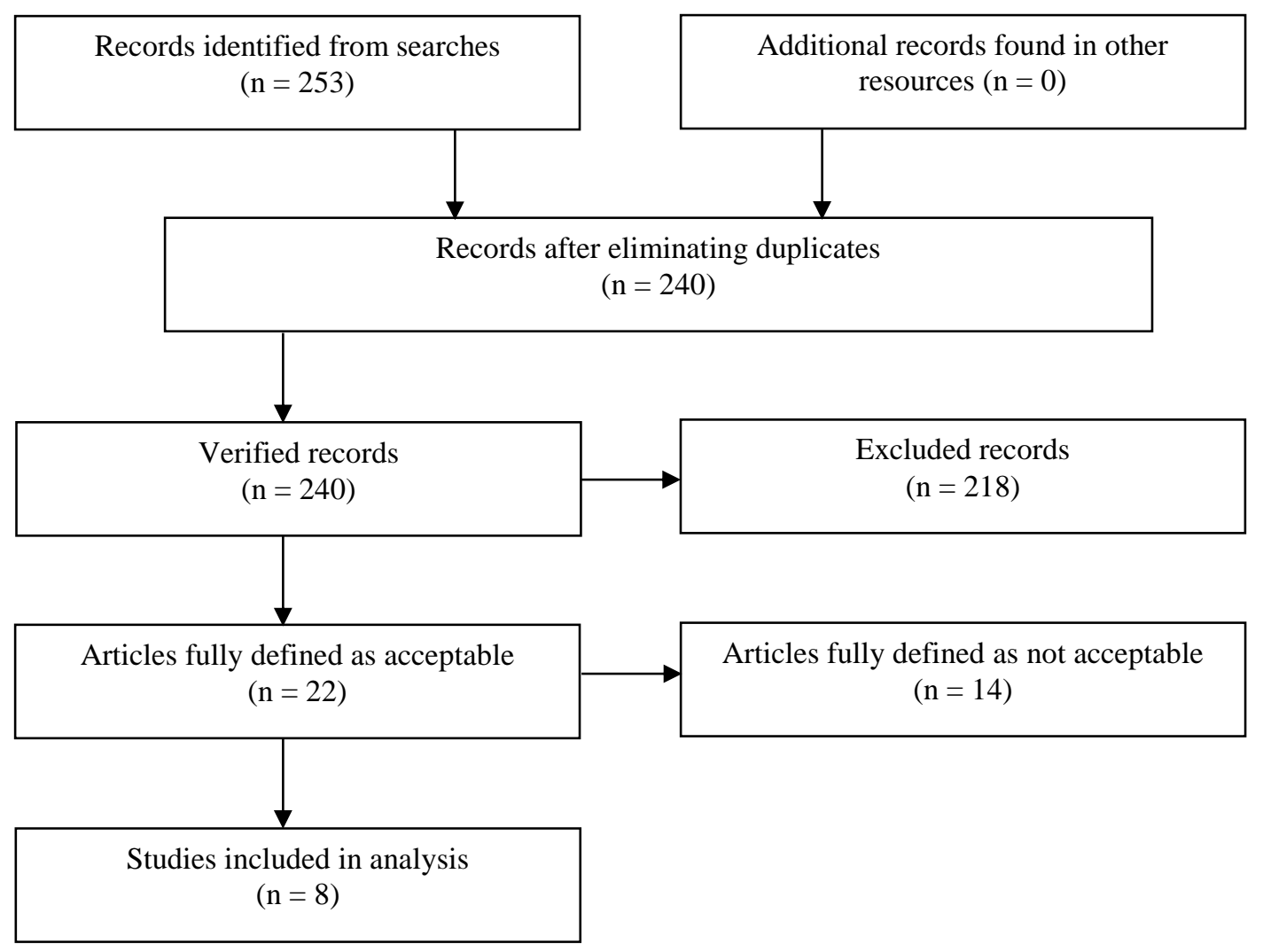

Figure 1 Procedure and results of selection process - flow diagram

\section{Results}

Measurement tools for the assessment of various aspects of delirium, such as severity and diagnostics, and the assessment of cognitive or motor symptoms of delirium have been examined in many studies. In the present study, we focused on screening tools that can be used for delirium detection in the postoperative period, and their implementation in clinical nursing practice. In the studies found dealing with screening of postoperative delirium, the following measurement tools were used: the Confusion Assessment Method for Intensive Care Units - CAM-ICU (Ely et al., 2001a), the Confusion Assessment Method - CAM (Inouye et al., 1990), the Nursing Delirium Screening Scale - Nu-DESC (Gaudreau et al., 2005), the NEECHAM Confusion Scale (Neelon et al., 1996), and the Intensive Care
Delirium Screening Checklist - ICDSC (Bergeron et al., 2001). An overview of cited studies matching the selection criteria is presented in Table 1.

Neufeld et al. (2013) compared use of the CAM-ICU and Nu-DESC screening tools with a standard neuropsychiatric examination performed by a medical specialist in psychiatry. Participants in the study were patients aged 70 and above $(n=91)$ placed in a postoperative unit in the immediate postoperative period, and, afterwards, daily during their hospitalization. The CAM-ICU and Nu-DESC used in the study demonstrated very low sensitivity and high specificity compared with a psychiatric examination focused on delirium screening. The authors therefore give precedence to psychiatric examinations for delirium screening, and do not consider CAM-ICU and Nu-DESC tools to be 
Table 1 Overview of the analyzed studies

\begin{tabular}{|c|c|c|c|c|}
\hline $\begin{array}{l}\text { Authors (year), } \\
\text { design of study }\end{array}$ & $\begin{array}{l}\text { Respondents, } \\
\text { clinical setting }\end{array}$ & $\begin{array}{l}\text { Measurement } \\
\text { tool }\end{array}$ & $\begin{array}{l}\text { Psychometric } \\
\text { characteristic }\end{array}$ & Practice recommendation \\
\hline $\begin{array}{l}\text { Neufeld et al. } \\
(2013) \\
\text { simple } \\
\text { prospective } \\
\text { centric study }\end{array}$ & $\begin{array}{l}\mathrm{n}=91 \\
\text { postoperative } \\
\text { unit }\end{array}$ & $\begin{array}{l}\text { CAM-ICU } \\
\text { Nu-DESC }\end{array}$ & $\begin{array}{l}\text { CAM-ICU and Nu-DESC versus } \\
\text { neuropsychiatric examination } \\
\text { show low sensitivity of CAM- } \\
\text { ICU }(28 \%) \text {, Nu-DESC ( } 32 \%) \text { and } \\
\text { high specificity CAM-ICU (over } \\
90 \%), \mathrm{Nu}-\mathrm{DESC}(69-96 \%)\end{array}$ & $\begin{array}{l}\text { for delirium screening it is } \\
\text { more appropriate to use } \\
\text { psychiatric examinations than } \\
\text { the CAM-ICU and Nu-DESC }\end{array}$ \\
\hline $\begin{array}{l}\text { Poikajärvi et al. } \\
\text { (2017) } \\
\text { randomized, } \\
\text { blinded study }\end{array}$ & $\begin{array}{l}\mathrm{n}=112 \\
\text { surgical ward }\end{array}$ & $\begin{array}{l}\text { NEECHAM } \\
\mathrm{Nu}-\mathrm{DESC} \\
\mathrm{CAM}\end{array}$ & $\begin{array}{l}\text { internal consistency of tools was } \\
\text { from } 0.76 \text { to } 0.86 \text {; concurrent } \\
\text { validity was } 0.56 \text { and } 0.59 \\
\text { between CAM and NEECHAM, } \\
\text { and } 0.68 \text { and } 0.72 \text { between } \\
\text { NEECHAM and Nu-DESC }\end{array}$ & $\begin{array}{l}\text { Optimal use of tools in a } \\
\text { clinical conditions; NEECHAM } \\
\text { - assessed by nurses as a time- } \\
\text { consuming tool }\end{array}$ \\
\hline $\begin{array}{l}\text { Nishimura et al. } \\
(2016) \\
\text { simple centric } \\
\text { study }\end{array}$ & $\begin{array}{l}\mathrm{n}=31 \\
\text { cardiac surgery }\end{array}$ & $\begin{array}{l}\text { CAM-ICU } \\
\text { ICDSC }\end{array}$ & $\begin{array}{l}\text { sensitivity of CAM-ICU was } \\
38 \% \text {, specificity was } 100 \% \text {; } \\
\text { sensitivity of ICDSC was } \\
94-97 \% \text {, CAM-ICU } \\
\text { demonstrates excellent inter-rater } \\
\text { reliability }\end{array}$ & $\begin{array}{l}\text { preference for ICDSC use } \\
\text { compared to CAM-ICU for } \\
\text { delirium screening in patient } \\
\text { population after cardiac surgery }\end{array}$ \\
\hline $\begin{array}{l}\text { Brooks et al. } \\
(2014) \\
\text { pilot study }\end{array}$ & $\begin{array}{l}\mathrm{n}=96 \\
\text { general surgery } \\
\text { department }\end{array}$ & $\begin{array}{l}\text { CAM } \\
\text { CAM-ICU }\end{array}$ & $\begin{array}{l}\text { CAM-ICU demonstrates } \\
\text { excellent reliability and validity }\end{array}$ & $\begin{array}{l}\text { CAM-ICU demonstrates } \\
\text { significant facilitation } \\
\text { regarding early detection of } \\
\text { postoperative delirium in a } \\
\text { population of surgical patients } \\
\text { aged } 65 \text { years and over }\end{array}$ \\
\hline $\begin{array}{l}\text { Ely et al. } \\
\text { (2001a) } \\
\text { prospective } \\
\text { cohort study }\end{array}$ & $\begin{array}{l}\mathrm{n}=38 \\
\text { intensive care } \\
\text { unit }\end{array}$ & CAM-ICU & $\begin{array}{l}\text { high inter-rater reliability in } \\
\text { patient assessment }(\kappa=0,84, \\
0,89 \text { a } 0,95) \text {; sensitivity of tool } \\
\text { was } 95 \%, 96 \% \text { and } 100 \% \\
\text { compared to the reference } \\
\text { standard - psychiatric } \\
\text { examination; specificity is } \\
89-93 \%\end{array}$ & $\begin{array}{l}\text { CAM-ICU tool is fast, valid } \\
\text { and reliable for the assessment } \\
\text { of delirium in intensive care } \\
\text { units and useful also for clinical } \\
\text { and research purposes, } \\
\text { possibility of its usage for } \\
\text { patients on artificial ventilation }\end{array}$ \\
\hline $\begin{array}{l}\text { Roberts et al. } \\
\text { (2005) } \\
\text { multi-centric } \\
\text { prospective study }\end{array}$ & $\begin{array}{l}\mathrm{n}=185 \\
\text { intensive care } \\
\text { unit }\end{array}$ & ICDSC & $\begin{array}{l}\text { acceptable validity and reliability } \\
\text { of the tool }\end{array}$ & $\begin{array}{l}\text { ICDSC is effective and } \\
\text { relatively simple for the user, } \\
\text { recommend inclusion of the } \\
\text { tool in patient documentation }\end{array}$ \\
\hline $\begin{array}{l}\text { Lingehall et al. } \\
\text { (2012) } \\
\text { prospective } \\
\text { observational } \\
\text { study }\end{array}$ & $\begin{array}{l}\mathrm{n}=142 \\
\text { cardiac surgery }\end{array}$ & $\mathrm{Nu}-\mathrm{DESC}$ & $\begin{array}{l}\text { sensitivitywas } 46,9-65,6 \% \text {, high } \\
\text { sensitivity todetection of } \\
\text { hyperactive form of delirium, but } \\
\text { low detection of hypoactive } \\
\text { form;specificity was } 94,9-97,8 \%\end{array}$ & $\begin{array}{l}\text { easy incorporation of the } \\
\text { instrument into clinical } \\
\text { practice, suitable for detection } \\
\text { of hyperactive and mixed form } \\
\text { of delirium }\end{array}$ \\
\hline $\begin{array}{l}\text { Winter, Steurer, } \\
\text { Dullenkopf } \\
\text { (2015) } \\
\text { prospective study }\end{array}$ & $\begin{array}{l}\mathrm{n}=1,000 \\
\text { postoperative } \\
\text { units of general } \\
\text { surgery, } \\
\text { orthopedics, } \\
\text { gynecology and } \\
\text { urology }\end{array}$ & $\mathrm{Nu}-\mathrm{DESC}$ & acceptable validity & $\begin{array}{l}\text { easy to use tool } \\
\text { in clinical practice }\end{array}$ \\
\hline
\end{tabular}

CAM-ICU - Confusion Assessment Method-Intensive Care Unit; Nu-DESC - Nursing Delirium Screening Scale; CAM - Confusion Assessment Method; ICDSC - Intensive Care Delirium Screening Checklist; $n$ - absolute frequency 
sufficiently sensitive in identifying postoperative delirium (Neufeld et al., 2013).

Poikajärvi et al. (2017) used NEECHAM and NuDESC tools on a sample of 112 patients undergoing surgical intervention, to establish which tool is most suitable for nurses for detecting delirium in patients. Patients were evaluated by two groups of evaluators - a principal investigator and registered nurses $(n=18)$. The aim of the study was the psychometric testing of these tools, using the CAM tool as a comparative scale. The study involved a thorough check of internal consistency of interrater reliability, and the validity and usability of the NEECHAM and $\mathrm{Nu}$-DESC in a clinical environment. Study results show that they are suitable for use in assessment of presence of delirium by nurses in clinical practice. Internal consistency of all the three tools oscillated between 0.76 and 0.86 . Interrater reliability between the principal investigator and registered nurses was 0.87 for the NEECHAM scale, 0.60 for the CAM scale, and 0.47 for the Nu-DESC scale. Concurrent validity was 0.56 and 0.59 between CAM and NEECHAM scales, and 0.68 and 0.72 between NEECHAM and Nu-DESC scales. The correlation between CAM and Nu-DESC scales identified by the principal investigator was 0.91 , and 0.42 by the group of registered nurses. Nurses reported the NEECHAM to be a time-consuming tool. In comparison with the CAM and NEECHAM tools, the study defines $\mathrm{Nu}-$ DESC as the most effective for screening of postoperative delirium (Poikajärvi et al., 2017).

Nishimura et al. (2016) examined the psychometric characteristics of the CAM-ICU and ICDSC screening tools, used for the screening of postoperative delirium in patients after cardiac surgery. Patients in their study $(\mathrm{n}=31)$ were assessed with the CAM-ICU and ICDSC tools by two nurses independently. The results were compared with the results of a psychiatric examination. The CAM-ICU demonstrated a sensitivity of $38 \%$ and $100 \%$ specificity; the ICDSC demonstrated a sensitivity between $94 \%$ and $97 \%$ and a specificity between $91 \%$ and $97 \%$. The CAM-ICU, however, demonstrated excellent interrater reliability when compared with the ICDSC (Nishimura et al., 2016).

Brooks et al. (2014) assessed patients aged 65 and above $(n=96)$ undergoing elective surgery, using the Mini-Cog assessment tool in the preoperative period, and the CAM or CAM-ICU in the postoperative period, depending on the unit where the patients were located after surgery. They reported that both the CAM and CAM-ICU demonstrated excellent reliability and validity, and significant facilitation regarding early detection of postoperative delirium (Brooks et al., 2014).

Ely et al. (2001a) published a prospective cohort study focusing on validation of the CAM-ICU tool. Patients $(\mathrm{n}=38)$ in intensive care units were assessed by two nurses and an intensive care specialist by means of the tool, and, in addition, they were examined by a neuropsychiatric specialist. The authors draw attention to the outstanding reliability and validity of the CAM-ICU, and the possibility of its use for patients on artificial ventilation. The study demonstrated high interrater reliability in the assessment performed by the intensive care specialist and two intensive care nurses $(\kappa=0.84,0.89$ and 0.95$)$. CAM-ICU sensitivity oscillated between $95 \%$ and $100 \%$ compared with a reference standard (neuropsychiatric examination). The specificity of the tool was superior (between $89 \%$ and $93 \%$ ). In the authors' evaluation, the CAMICU tool is fast, valid, and reliable for the assessment of delirium in intensive care units, and also suitable for clinical and research purposes (Ely et al., 2001a).

Roberts et al. (2005) describe the usage of the ICDSC tool in selected intensive care units. Patients involved in the study $(\mathrm{n}=185)$ were assessed by this tool at intervals of 12 hours in two periods. The authors conclude that the tool is effective and easy to use in clinical practice (Roberts et al., 2005).

Lingehall et al. (2012) tested usage of Nu-DESC for cardiac surgical patients $(n=142)$. The patients were assessed by means of the Nu-DESC, while the Mini Mental Test Examination, and the Organic Brains Syndrome Scale were used as comparative tools. The authors demonstrated the ease with which the Nu-DESC could be incorporated into clinical practice, and its high sensitivity in the detection of hyperactive delirium. However, due to its low sensitivity in the detection of hypoactive delirium, they recommend combining the Nu-DESC with cognitive testing of patients, in order to reliably identify this form of delirium (Lingehall et al., 2012).

Winter, Steurer, Dullenkopf (2015) also conducted a study on the use of the Nu-DESC, in which the respondents were patients hospitalised in postoperative units $(n=1,000)$ in general surgery, orthopaedics, gynaecology, and urology. Their study showed the ease of use of the Nu-DESC. According to the authors, the study had limitations that may have affected its results: i.e., a low delirium incidence in the research sample, due to the low age of the patients (57.3 $\mathrm{SD} \pm 18.1)$ and their relatively good state of health (Winter, Steurer, Dullenkopf, 2015). 


\section{Discussion}

The most tested and globally most recommended tool for the screening of postoperative delirium is the Confusion Assessment Method-Intensive Care Unit CAM-ICU. It is believed to be the standardized tool most commonly used by specialists from a nonpsychiatric environment for delirium detection (Mitášová et al., 2010). The CAM-ICU was adapted by Ely et al. (2001a) from The Confusion Assessment Method (CAM) for delirium detection by specialists without specific training in psychiatry. The tool assesses presence, severity, and oscillation of nine delirium symptoms: acute start, inattention, disorganized thinking, altered conscience, disorientation, memory disorders, perception disorders, psychomotor agitation or retardation, and disorders of the sleep-wake cycle (Inouye et al., 1990; Ely et al., 2001a). Assessment of delirium in a patient by means of the CAM-ICU (in contrast to the CAM) involves two steps (Ely et al., 2001a). The first is the assessment of sedation and agitation level by means of The Richmond Agitation and Sedation Scale - RASS (Sessler et al., 2002), which can affect the result of the CAM-ICU. If, after RASS administration, the result is higher than a score of -4 , the second step - testing a patient by means of the CAM-ICU - proceeds. The tool has been translated and validated in several languages, e.g., German, Spanish, Portuguese, Korean, and Czech (GusmaoFlores et al., 2012). The CAM-ICU tool has not yet been validated in Slovakia and the Czech Republic. However, the CAM tool has been researched by Vörösová (2010) in both countries. From her findings, she concludes that the CAM is a valid screening tool for fast delirium diagnostics, and also for diagnostics of nursing diagnosis of Acute Confusion in clinical practice (Vörösová, 2010).

Brooks et al. (2014) point to the advantages of the CAM-ICU tool, such as, early detection of delirium, and its significant facilitation of early detection of postoperative delirium (Brooks et al., 2014). Friedman et al. (2008) emphasize the advantage of early delirium detection, relative time efficiency, and ease of use by medical staff without specific training in psychiatry (Friedman et al., 2008). Jung et al. (2013) state that early delirium detection and adequate intervention are crucial for management of delirium, as well as for patient safety. Delirium can also cause stress or trauma in hospitalized patients, such as injuries resulting from falls, and extubation or disconnection from a machine or therapeutic device (Jung et al., 2013). Ely et al. (2001a) stress the effectiveness of the CM-ICU tool for clinical as well as research purposes.
The advantage and uniqueness of this tool is that it can be used for patients on artificial ventilation, as confirmed by another study by Ely et al. (2001b) focusing on delirium screening in mechanically ventilated patients. They demonstrate the outstanding reliability and validity of the CAM-ICU, and consider it a reliable tool for delirium diagnostics in intensive care units (Ely et al., 2001a; Ely et al., 2001b). Nishimura et al. (2016) point out the excellent interrater reliability of the CAM-ICU, but note its lower sensitivity in comparison with the ICDSC tool. Mitášová et al. (2010) similarly state that ICDSC has high sensitivity but lower specificity when compared with the CAM-ICU. Nishimura et al. (2016) therefore favour use of the ICDSC in the population of cardiac surgery patients (Mitášová et al., 2010; Nishimura et al., 2016). The ICDSC tool, created and validated by Bergeron (2001), involves eight items related to aspects of patient behaviour over the previous 24 days, and is based on criteria for delirium diagnostics according to the DSM IV - the Diagnostic and Statistical Manual of Mental Disorders, 4th Edition, Text Revision (Bergeron et al., 2001; Gusmao-Flores et al., 2012). A different view is expressed by Plaschke et al. (2008), who point out the high accordance between these tools $(\kappa \doteq 0.80)$, and consider both to be useful for practice (Plaschke et al., 2008).

The lower sensitivity of the CAM-ICU is noted by Neufeld et al. (2013) who examined the sensitivity and specificity of both the CAM-ICU and Nu-DESC. The Nu-DESC screening tool was created by a work group for Gaudreau et al. (2005). It is a scale of five items focusing on assessment of disorientation, inappropriate behaviour, inappropriate communication, hallucination, and psychometric retardation. The tool has been created and designed in a way that enables clinical observation of a patient by a nurse during routine nursing care (Gaudreau et al., 2005). Neufeld et al. (2013) do not consider use of the CAM-ICU and Nu-DESC tools effective for routine screening of postoperative delirium due to their low sensitivity in comparison to a psychiatric examination. They recommend a neuropsychiatric examination of patients for this screening. However, van den Boogaard, Pickkers, Schoonhoven (2010) suggest that standard diagnosis of delirium by means of psychiatric examination is difficult to perform in clinical practice, especially in intensive care units, due to the fluctuating nature of delirium, as well as the fact that delirium symptoms typically appear in the evening hours (sundown syndrome) when the presence of a psychiatrist in a medical facility is not guaranteed (van den Boogaard, Pickkers, Schoonhoven, 2010). For these reasons, nurses play 
a key role in patient observation, symptom identification, and communication of delirium symptoms to a doctor (Poikajärvi et al., 2017). However, several authors state that doctors and nurses are often insufficiently capable of identifying delirium, especially in hypoactive form, leading to its underdiagnosis (Inouye et al., 1990; van den Boogaard, Pickkers, Schoonhoven, 2010; Harroche, St-Louis, Gagnon, 2014). According to Inouye et al. (1990), the main cause of this situation is the insufficient use of a relevant tool for delirium assessment (Inouye et al., 1990).

Another tool recommended for the identification of postoperative delirium by nurses, is the NEECHAM Confusion Scale, according to Poikajärvi et al. (2017). However, they point out that administration of the tool is time-consuming, which is a serious limitation on its routine use. The NEECHAM assesses patients' behaviour during care provision. It involves three subscales focusing on assessment of cognitive processes, behaviour, and objectivization of physiological processes (Neelon et al., 1996; Poikajärvi et al., 2017). Use of this tool for nursing diagnosis of Acute Confusion was also examined in Slovak nursing practice by Vörösová (2007).

Despite serious limitations to our overview study, which was based solely on searching full-text studies in databases available to Comenius University in Bratislava, our findings were similar to those of other authors - Grover, Kate (2012), GusmaoFloreset al. (2012), De, Wand (2015) - who describe the importance of the use of measurement tools for the screening of postoperative delirium, particularly the CAM-ICU, ICDSC, Nu-DESC, and NEECHAM, regarding subsequent optimum management of patients (Grover, Kate, 2012; Gusmao-Floreset al., 2012; De, Wand, 2015).

\section{Conclusions}

The results of the studies analysed demonstrate the importance of implementation of a relevant tool for the screening of postoperative delirium. Following our analysis, the CAM-ICU tool is most highly recommended for the detection of postoperative delirium. Administration of the tool is time-efficient, and it is also easy for nurses to use even without psychiatric specialization. The CAMICU also has optimum psychometric characteristics. Since in Slovak clinical practice the use of screening tools for early and systematic detection of postoperative delirium are lacking, it is essential to examine the psychometric characteristics and usability of screening tools for postoperative delirium for their implementation into practice.

\section{Ethical aspects and conflict of interest}

All bibliographical resources used are properly referenced. The author declares no conflict of interest.

\section{Author contribution}

Conception and design (MB, MT), data analysis and interpretation of data (MB), drafting the manuscript (MB), critical revision of the manuscript (MT), the final completion of the article (MB).

\section{References}

Bergeron N, Dubois MJ, Dumont M, Dial S, Skrobik Y. Intensive Care Delirium Screening Checklist: evaluation of a new screening tool. Intensive Care Medicine. 2001;27(5):859-864.

Bóriková I. Funkčný stav seniora. 1. vyd. Martin: JLF UK; 2015. (in Slovak)

Brooks P, Spillane JJ, Dick K, Stuart-Shor E. Developing a strategy to identify and treat older patients with postoperative delirium. AORN Journal. 2014;99(2):257-273.

De J, Wand AP. Delirium screening: a systematic review of delirium screening tools in hospitalized patients. The Gerontologist. 2015;55(6):1079-1099.

Doubek P, Jirák R. Delirium. In: Raboch J, Pavlovský P, editors. Psychiatrie. Praha: Univerzita Karlova v Praze; 2013. s. 197-207. (in Czech)

Ely EW, Margolin R, Francis J, May L, Truman B, Dittus R, Speroff T, Gautam S, Bernard GR, Inouye SK. Evaluation of delirium in critically ill patients: validation of the Confusion Assessment Method for the Intensive Care Unit (CAM-ICU). Critical Care Medicine. 2001a;29(7):1370-1379.

Ely EW, Inouye SK, Bernard GR, Gordon S, Francis J, May L, Truman B, Speroff T, Gautam S, Margolin R, Hart RP, Dittus R. Delirium in mechanically ventilated patients: validity and reliability of the confusion assessment method for the intensive care unit (CAM-ICU). JAMA. 2001b;286(21):2703-2710.

Friedman Z, Qin J, Berkenstadt H, Katznelson R. The confusion assessment method - a tool for delirium detection by the acute pain service. Pain Practice. 2008;8(6):413-416. Gaudreau JD, Gagnon P, Harel F, Tremblay A, Roy MA. Fast, systematic, and continuous delirium assessment in hospitalized patients: the nursing delirium screening scale. Journal of Pain and Symptom Management. 2005;29(4):368375.

Grover S, Kate N. Assessment scales for delirium: a review. World Journal of Psychiatry. 2012;2(4):58-70.

Gusmao-Flores D, Salluh JI, Chalhub RÁ, Quarantini LC. The confusion assessment method for the intensive care unit (CAM-ICU) and intensive care delirium screening checklist (ICDSC) for the diagnosis of delirium: a systematic review and meta-analysis of clinical studies. Critical Care. 2012;16(4):R115.

Harroche J, St-Louis L, Gagnon M. The detection of delirium in the ICU: an important aspect of care. Journal of Nursing Education and Practice. 2014;4(9):135-145. 
Inouye SK, van Dyck CH, Alessi CA, Balkin S, Siegal AP, Horwitz RI. Clarifying confusion: the confusion assessment method. A new method for detection of delirium. Annals of Internal Medicine. 1990;113(12):941-948.

Jirák R. Deliria - závažný a nedoceněný problém gerontopsychiatrie. Psychiatrie pro praxi. 2005;6(2):72-74. (in Czech)

Jung JH, Lim JH, Kim EJ, An HC, Kang MK, Lee J, Min YK, Park EZ, Song XH, Kim HR, Lee SM. The experience of delirium care and clinical feasibility of the CAM-ICU in a Korean ICU. Clinical Nursing Research. 2013;22(1):95-111. Lingehall HC, Smulter N, Engström KG, Gustafson Y, Olofsson B. Validation of the Swedish version of the Nursing Delirium Screening Scale used in patients 70 years and older undergoing cardiac surgery. Journal of Clinical Nursing. 2012;22(19-20):2858-2866.

Mitášová A, Bednařík J, Koštálová M, Michalčáková R, Ježková M, Kašpárek T, Skutilová S, Straževská E, Šályová P, Šikolová V, Šrámková L. Standardizace české verze The Confusion Assessment Method for the Intensive Care Unit (CAM-ICUcz). Česká a Slovenská Neurologie a Neurochirurgie. 2010;73/106(3):258-266. (in Czech)

Mitášová A, Mitáš L, Urbánek I, Ryba L, Hanke I, Ruber M, Michalčáková $\mathrm{R}$, Koštálová $\mathrm{M}$, Bednařík J. Incidence a rizikové faktory pooperačního deliria. Česká a Slovenská Neurologie a Neurochirurgie. 2012;75/108(5):574-580. (in Czech)

Neelon VJ, Champagne MT, Carlson JR, Funk SG. The NEECHAM Confusion Scale: construction, validation, and clinical testing. Nursing Research. 1996;45(6):324-330.

Neufeld KJ, Leoutsakos JS, Sieber FE, Joshi D, Wanamaker BL, Rios-Robles J, Needham DM. Evaluation of two delirium screening tools for detecting post-operative delirium in the elderly. British Journal of Anaesthesia. 2013;111(4):612-618. Nishimura K, Yokoyama K, Yamauchi N, Koizumi M, Harasawa N, Yasuda T, Mimura C, Igita H, Suzuki E, Uchiide Y, Seino Y, Nomura M, Yamazaki K, Ishigooka J; TMAD investigators. Sensitivity and specificity of the Confusion Assessment Method for the Intensive Care Unit (CAM-ICU) and the Intensive Care Delirium Screening Checklist (ICDSC) for detecting post-cardiac surgery delirium: a single-center study in Japan. Heart and Lung. 2016;45(1):15-20.

Plaschke K, von Haken R, Scholz M, Engelhardt R, Brobeil A, Martin E, Weigand MA. Comparison of the confusion assessment method for the intensive care unit (CAM-ICU) with the Intensive Care Delirium Screening Checklist (ICDSC) for delirium in critical care patients gives high agreement rate(s). Intensive Care Medicine. 2008;34(3):431436.

Poikajärvi S, Salanterä S, Katajisto J, Junttila K. Validation of Finnish Neecham Confusion Scale and Nursing Delirium Screening Scale using Confusion Assessment Method algorithm as a comparison scale. BMC Nursing. 2017;16:7.

Praško J, Suchý A, Kubínek R. Psychopatologie. In: Praško J, editor. Obecná psychiatrie. Olomouc: Univerzita Palackého v Olomouci, Lékařská fakulta; 2011. s. 53-140. (in Czech)

Roberts B, Rickard CM, Rajbhandari D, Turner G, Clarke J, Hill D, Tauschke C, Chaboyer W, Parsons R. Multicentre study of delirium in ICU patients using a simple screening tool. Australian Critical Care. 2005;18(1):6,8-9.

Sessler CN, Gosnell MS, Grap MJ, Brophy GM, O’Neal PV, Keane KA, Tesoro EP, Elswick RK. The Richmond Agitation-Sedation Scale: validity and reliability in adult intensive care unit patients. American Journal of Respiratory and Critical Care Medicine. 2002;166(10):1338-1344.

Uhrová T, Klempír J. Delirium - obecný úvod do problematiky. Neurologie pro praxi. 2011;12(5):304-306. (in Czech)

van den Boogaard M, Pickkers P, Schoonhoven L. Assessment of delirium in ICU patients: a literature review. Netherlands Journal of Critical Care. 2010;14(1):10-15.

Vörösová G. Overovanie určujúcich znakov akútnej zmätenosti na vybraných pracoviskách. In: Bužgová R, Jarošová $\mathrm{D}$, editors. Ošetřovatelská diagnostika a praxe založená na di̊kazech. Ostrava: Ostravská univerzita v Ostravě, Zdravotně sociální fakulta; 2007. s. 85-89. (in Slovak)

Vörösová G. Vnútorná konzistencia škály CAM na posúdenie akútnej zmätenosti v podmienkach Slovenskej a Českej republiky. Ošetřovatelství a porodní asistence. 2010;1(3):99105. (in Slovak)

Winter A, Steurer MP, Dullenkopf A. Postoperative delirium assessed by post anesthesia care unit staff utilizing the Nursing Delirium Screening Scale: a prospective observational study of 1000 patients in a single Swiss institution. BMC Anesthesiology. 2015;15:184.

Wofford K, Vacchiano C. Sorting through the confusion: adverse cognitive change after surgery in adults. AANA Journal Course. 2011;79(2):335-342.

Zmeková J. Deliriózní stavy nealkoholové etiologie. Psychiatrie pro praxi. 2003;4(3):108-111. (in Czech) 